\title{
STRATEGIC PLANNING IN BRAZILIAN SMALL-SCALE MUNICIPALITIES: IS THE BALANCED SCORECARD A FEASIBLE TOOL?
}

\author{
PLANEJAMENTO ESTRATÉGICO EM MUNICÍPIOS \\ BRASILEIROS DE PEQUENO PORTE: \\ SERIA O BALANCED SCORECARD UMA \\ FERRAMENTA VIÁVEL?
}

Recebido $11 / 03 / 2013$ Aceito $21 / 08 / 2013$

Ricardo Corrêa Gomes ${ }^{1}$ Viviani Silva Lírio ${ }^{2}$

\begin{abstract}
Balanced Scorecard has not yet been tested in Brazilian small-scale municipalities. The BSC is based on dimensions of Learning and Growth, Internal Processes Business, Financial and Customer. In order to fit to public organizations it needs some adjustments due to these organizations' objectives. This paper presents a case study focusing on municipalities from Brazil. Data has been collected by action research and analysed by qualitative analysis. The analysis indicates that the BSC can be easily implemented in small-scale municipalities. It soundly depends on Mayor's leadership and staff's engagement. The way it is put to practice is also important. By keeping it as easier as possible, civil servants are more able to participate and to collaborate to the process.
\end{abstract}

Keywords: Balanced Scorecard; Municipalities; Action Research; Brazil.

\footnotetext{
${ }^{1}$ Possui graduação em Administração pela Fundação Educacional Serra dos Órgãos, mestrado em Administração pela Fundação Getúlio Vargas - FGV, doutorado em Administração Pública na Universidade de Aston - Reino Unido e pós-doutorado na Georgia State University - Estados Unidos. Atualmente é professor associado na Universidade de Brasília - UnB. Brasília, Distrito Federal, Brasil. E-mail: rgomes@unb.br.

2 Possui graduação em Ciências Econômicas pela Universidade Federal do Espírito Santo - UFES e doutora em Economia Rural pela Universidade Federal de Viçosa - UFV. Atualmente é professora do Departamento de Economia Rural da Universidade Federal de Viçosa - UFV. Viçosa, Minas Gerais, Brasil. E-mail: vslirio@ufv.br.
} 


\section{RESUMO}

O Balanced Scorecard ainda não foi testado em municípios brasileiros de pequeno porte. O BSC é baseado nas dimensões de aprendizado e crescimento, processos internos, financeira e clientes. De modo a ser melhor adaptado a organizações públicas, a ferramenta precisa de alguns ajustes em função das objetivos que guiam estas organizações. Este artigo apresenta um estudo de caso realizado em um município de pequeno porte no Brasil. Os dados foram coletados através da estratégia de pesquisa pesquisa-ação e foram analisados por técnicas qualitativas. A análise indica que o BSC pode ser facilmente utilizado por prefeituras de pequeno porte. Tudo depende da liderança do prefeito em todo o processo e do engajamento dos secretários e dirigentes. A forma com que a ferramenta é implementada também é um fator crucial. O importante é não complicar para que os servidores públicos em todos os níveis possam participar e colaborar em todo o processo.

Palavras-chave: Balanced Scorecard; municípios de pequeno porte; pesquisa-ação; Brasil

\section{INTRODUCTION}

After the advent of the New Public Management (NPM), public sector managers and scholars became much more aware of the importance of managing this particular type of organization by using tools supposed to improve efficiency, effectiveness and transparency (Moynihan et al., 2011). In this wave, an abundance of studies, papers and books attempted to understand and to set mechanisms for making public organizations more private alike (Hood, 1995a, Moynihan and Pandey, 2010, Berman, 2006).

One of the most famous of such mechanism is indubitably the Balanced Scorecard, which is a strategy formulation device proposed by Kaplan and Norton (1992). This device has as a starting point the organization's vision of future and from this, it create the conditions for setting objectives, targets, actions, all of this controlled by performance indicators. It is a largely implemented tool in the private sector with some experiences in the public sector, mainly on nonprofit organizations (Kaplan and Norton, 2001, Silva and Gonçalves, 2011, Cruz et al., 2010). There are even some experiences of using the BSC as strategy development device in government (Carmona and Grönlund, 2003, Moynihan and Pandey, 2010), but there are few empirical evidences supporting it as a useful tool for this multicustomer and multistakeholder organization (McAdam et al., 2005, Yetano, 2009, Farneti and Guthrie, 2008) .

The Balanced Scorecard (BSC) has not previously been tested in Brazilian small-scale municipalities as a tool for managing performance. Due to the lack of evidence and the idiosyncratic nature of the tool it is not clear whether this approach to performance appraisal is generalisable across all jurisdictions. There is evidence that BSC has been employed in the USA and Canada (Chan, 2004), Great Britain (Wisniewski and Olafsson, 2004), Australia (Yetano, 2009, Farneti and Guthrie, Hoque, 2008), New Zealand (Greatbanks and Tapp, 2007), Italy (Farneti and Guthrie, 2008), and Norway (Askim, 2004), among other countries. However, there is limited research on its use in developing countries. Due to the apparent gaps in literature, this paper aims to contribute to local government performance management by adding key variables, and assessing whether BSC can be successfully and feasibly employed in local government in developing countries.

This paper presents an investigation carried out with the City if Guarani, a small-scale municipal district from Brazil in a two years period of time from 2006 to 2007. Data has been collected by action research and grounded theory and analysed through interpreting raw data with researchers' subjectivity. At the end, the paper aims to contribute to local government management theory by providing empirical evidence on the process of putting the BSC to practice in a small-scale municipality in Brazil. 
The paper is structured in order to devise a comprehensive theoretical framework for explaining:

- Why performance management has become so important to government?

- What are the frameworks managers have been using to improve performance?

- What is the BSC's role in this endeavour? And, as the main research question

- Is the BSC a feasible tool for helping mayors to devise strategies for improving performance?

\section{THEORETICAL FRAMEWORK}

\subsection{Why Performance Management has become so important?}

Performance management has been on scholars' agenda since 1980's. In great measure influenced by Peters and Waterman's (1982) landmark book In search of the Excellence, whose main objective was to depict the determinant factors that leads an organization to superior performance. At the same decade, Porter (1985) launched his ideas about performance management in the business sector in the book Competitive Advantage: Creating and Sustaining Superior Performance, in which he proposed the famous 'diamond'. Later on and after investigating countries from four continents, Porter (1998) launched his ideas about the competitive advantage that would make a difference between developed and in developing countries in the book The Competitive Advantage of Nations. According to this author, performance is very likely to be seen as the result of the adequate management of external and internal factors, which leads a country either to superior or to inferior performance.

For-profit organizations, on their turn, are created to seek financial results for their stockholders. On the other hand, public organizations have neither owners nor shareholders. They are entitled to serve the local population instead. In this vein, power in public organizations is a temporary issue, because it is the result of a mandate exerted by politicians on behalf of their constituencies. Such idiosyncrasies place public and private organizations in different sides in terms of the exercising of power. Besides these differences in nature and objectives, the great majority of public managers focus utterly on financial measures for assessing the performance of public organizations, such as fiscal surplus/debits (1996).

Nowadays, this paradigm has changed and public managers have been more concerned with other types of performance measures in order to ensure superior performance. Kaplan and Norton (1991), Porter (1996), and Woods (Woods and Grubnic, 2008) challenged this assumption indicating that organizations need to develop more comprehensive performance indicators in order to fully understand the organization's operation and the environment in which it is embedded. According to Kaplan and Norton (Kaplan and Norton, 1992), financial measures should be complemented with information from internal processes, customer's requirements and organizational learning and innovation(2006, p. 9).

\subsection{Performance Management in the Public Sector}

Lebas (1995, p. 23) argued about the difficult to precisely define the term performance, which "can mean anything from efficiency, to robustness or resistance or return on investment, or plenty of other definitions never fully specified". According to Berman(Berman, 2006, p. 65, 1995, p. 65), "performance is defined as the effective and efficient use of resources". Sinclair and 
Zairi (Sinclair and Zairi, 1995, Ball, 1998) defined performance management as "the day-to-day management of individuals based on performance measurement".

Due to differences on nature and mission, public organizations need to be looked upon in order to cover managerial as well as political aspects (Kaplan and Norton, 2001). In the same vein, Kaplan and Norton (2001, p. 98), suggested that the non-for-profit organizations should put constituencies at the top of their strategic maps, by arguing that "... in a nonprofit organization, donors provide the financial resources - they pay for the service - while another group, the constituents, receives the service. Who is the customer - the one paying or the one receiving?"

The concern about performance management in the public sector started with the advent of New Public Management (NPM), which according to Hood (1995b) involved a different conception of accountability. The basic assumptions NPM is based upon reducing differences between public and private organizations and more emphasis on results rather than processes (Lee, 2006). In the same vein, Hood (1991) proposed a framework for understanding NPM rationale, which is split of into two main lines: the adoption of a 'new' structure and the adoption of business based procedures. Table 1 presents these two lines and how public organizations are being transformed.

Table 1 - NPM conceptual main lines

\begin{tabular}{|c|c|}
\hline Doctrine & Innovations \\
\hline Public Sector Distinctiveness & $\begin{array}{l}\text { 1. Adoption of units based on products rather than functions; } \\
\text { 2. Services provision based on contracts; } \\
\text { 3. Adoption of private sector management styles; } \\
\text { 4. Cost reductions; }\end{array}$ \\
\hline Rules versus Discretion & $\begin{array}{l}\text { 1. Clear assignment of responsibility; } \\
\text { 2. Adoption of formal measurable standards of performance; } \\
\text { 3. Stress on results }\end{array}$ \\
\hline
\end{tabular}

Source: Adapted from Hood (1995b)

Given the seven differences between new and old public management (Riccucci, 2001), we realized a great deal of attention to the innovation number six and a flood of initiatives on performance management and measurement has been engulfing government and non-profit organization where public managers are trying to make things more reasonable for themselves and for society.

\subsection{Performance Measurement in the Public Sector: the use of the BSC}

Public sector organizations have employed more and more performance indicators as a tool to control performance (Kaplan and Norton, 2001). They develop tools from several frameworks, such as business excellence model, Investors in People), charter mark, ISO 9000, the balanced scorecard and benchmarking (Chan, 2004). Another list of performance frameworks are suggested by Wisniewski (2004) and they are the performance pyramid, the results and determinants matrix, the Balanced Scorecard, the consistent performance measurement system, and the integrated performance measurement system. The common point between the two lists is the Balanced Scorecard.

According to Kaplan and Norton (1996, p. 25), "the Balanced Scorecard translates mission and strategy into objectives and measures, organized into four different perspectives: financial, customer, internal business process, and learning and growth." They (1996, p. 25) also added "the four perspectives of the scorecard permit a balance between short-and long-term objectives, 
between outcomes desired and the performance drivers of those outcomes, and between hard objectives measures and softer, more subjective measures." In Kaplan and Norton's view (1996), strategies are developed following a cause and effect approach. In this vein, "...measurement system should make the relationship (hypotheses) among objectives (and measures) in the various perspectives explicit so that they can be managed and validated (Kaplan and Norton, 1996, p. 30). For example, investments in learning will lead to a better internal business processes, which, in turn, is likely to improve customer's satisfaction and loyalty, and therefore ending up in a higher return on investments, which would satisfy shareholders (Greatbanks and Tapp, 2007).

After being implemented in a huge amount of business-based organizations, we now realize its application to public organizations. There is evidence that BSC has been employed in the USA and Canada (Askim, 2004), Great Britain (Kaplan and Norton, 2001), Australia (Yetano, 2009, Farneti and Guthrie, 2008, Hoque, 2008), Italy (Farneti and Guthrie, 2008), New Zealand (Kaplan and Norton, 2001, Greatbanks and Tapp, 2007), Norway (Chan, 2004, p. 216), among other countries. Despite being widespread in developing countries, there is few empirical evidence in literature about the application of the balanced scorecard (BSC) in developing countries (Gomes and Liddle, 2009, Ruas, 2003), but no evidence whatsoever for the specific case of Brazilian small-scale municipalities.

Lee (2006, p. 52) argued that the following characteristics legitimate the BSC as a useful framework for improving performance and they are:

- Derived from strategy;

- Stimulate continuous improvement;

- Clearly defined purpose;

- Simple to understand and use.

According to Kaplan and Norton (Kaplan and Norton, 1996), the BSC needs some adjustments in order to fit to non-for-profit organizations modus operandi, because their main objectives are not finance-related. They suggested putting the customer (better saying constituencies) at the top of the strategic map. But, even this small alteration could be a tricky one. Kaplan and Norton (2001, p. 98), argued that "... in a nonprofit organization, donors provide the financial resources - they pay for the service - while another group, the constituents, receives the service. Who is the customer - the one paying or the one receiving?" For this strategic problem, they suggested that "organizations place both the donor perspective and the recipient perspective, in parallel, at the top of their Balanced Scorecards"(Kaplan and Norton, 2001, p. 98, Kloot, 1999)

Radnor and Lovell (2003) prevent about some key-measures who are to be met in order to ensure the implementation of the BSC in public service organizations (in their case Health Care Organizations in the UK).

- Demonstrating the BSC's theoretical and practical potential to add service value;

- Obtain support to introduce the BSC;

- Do not ignore past experiences.

In the same vein, Chan(Chan, 2004)concluded about the effort of putting the BSC to run in public organizations as a set of eight factors:

- top management commitment and leadership buy-in;

- departmental, middle-manager and civil servant participation and buy-in; 
- culture of performance excellence;

- training and education;

- keeping it relatively simple, easy to use and understand;

- clarity of vision, strategy and outcome;

- link of balanced scorecard to incentive; and

- resources to implement system.

Considering the ideas outlined above, we don't know yet whether the BSC helps small-scale municipal districts to devise better strategic plans. And this doubt derives from the idiosyncrasy of such type or organizations. In Brazil, more than $90 \%$ of the municipal districts have less than 50.000 inhabitants (Brasil, 2011). The city hall is very close to the local population and the Mayor, in the majority of the cases, manages the budget as its own 'wallet'. The literature offers, as stated before, some experiences of implementations of the BSC in public sector organizations, but none whatsoever on Brazilian municipal districts. One explanation for this fact could rely upon either the great difficult on implementing this tool on a rather multi-client and multi-stakeholder organization, or due to mistrust of public sector managers on tools imported from private sector. Another difficulty we see before going deeper on the analysis is about the electoral process itself, which states that local population should be consulted every four years about who are to be in charge of its destiny for the period ahead.

The review on literature presented above leads us to think about the feasibility of implementing the BSC in a small-scale municipal district and the following research question arises, which is inspired on Yetano's work(2009): How small-scale municipal districts in developing countries react to the implementation of the Balanced Scorecard as a strategic management tool?

\section{METHODOLOGY}

Given the research question proposed above, the investigation was designed to figure out whether the BSC is accepted by small-scale municipal districts as a feasible strategic and performance management framework. In order to fulfill this question, the most suitable research strategy seems to be the case study, which according to Yin (2003, p. 23) is "...an empirical inquiry that investigates a contemporary phenomenon within its real-life context..." Yin (2003) also argued that case studies are indicated when the investigation does not requires control of behavioral events, and when it focuses on contemporary events. According to Yin (2003), case studies can be designed either as single or multiple, looking at the case as whole (holistic), or units of the case (embedded). Single case studies should be a genuine, extreme or unique representation of its class. It also should be a typical case. In this investigation, we have chosen the Municipal District of Guarani due to its representativeness of being a small-scale municipal district that demonstrated interest on trying the BSC as its strategy and performance management tool.

As a research approach, we chose the action research due to its flexibility of involving respondents in data collection and analysis (Moss et al., 2007). According to Bryman (2008) is an approach in which the researcher and a client collaborate in the diagnosis of a problem and in the development of a solution based on such diagnosis. Data was mainly qualitative and collected by semi-structured interviews and focus group. For collecting data, meeting were set up with the Mayor, Vice-Mayor, and whole secretariat group, including the Secretariats of Health, Education, Social Services, Administration, Finance, Housing, the General Attorney, Accounting and other services. The four sessions comprised the data collection process and it happened as follows. In a first meeting with the Mayor and the Vice-Mayor, the main objectives and a timeframe and 
schedule for the sessions were defined. In a second session, the Mayor indicated the overall aims of his administration and what he did expected from the most important areas of the municipality in terms of goals. The third section was a round of focus group session with ten people, where some secretariats and senior officers did attend in order to indicate achieve consensus about the main objective of each area. The last session was another focus group to define targets for each area and feasible performance indicates to compose the BSC. The whole amount of data was analyzed according to the interpretative paradigm (Bryman, 2008) and by content.

\subsection{The identification of the research locus}

Guarani is regarded as a small-scale municipal district due to its population size. According to the 2007 Demographic census (Brasil, 2007), Guarani has 9,487 inhabitants scattered throughout $264 \mathrm{Km}^{2}$. Table 2 presents the economic sector and the percentage of the population employed in each sector. Data indicates that more than $40 \%$ of the population is employed in the services sector with a preponderance of civil servants in this figure. The city is located at the southeast of the State of Minas Gerais and at 276km from its capital - Belo Horizonte as Figure 1 illustrates. Its secondary sector is based on manufacture of goods, mainly textile; chemicals; and the manufacture of food.

Table 2 - The Frequency Distribution of the Economically Active Population

\begin{tabular}{l|c}
\hline Economic sectors & Percentage of the population employed \\
\hline Agriculture, Extractives and Fisheries & $27 \%$ \\
Industry & $21 \%$ \\
Commerce & $11 \%$ \\
Services & $41 \%$ \\
\hline TOTAL & $100 \%$ \\
\hline Source: Data Findings
\end{tabular}

Figure 1 - The location of the city within the State of Minas Gerais

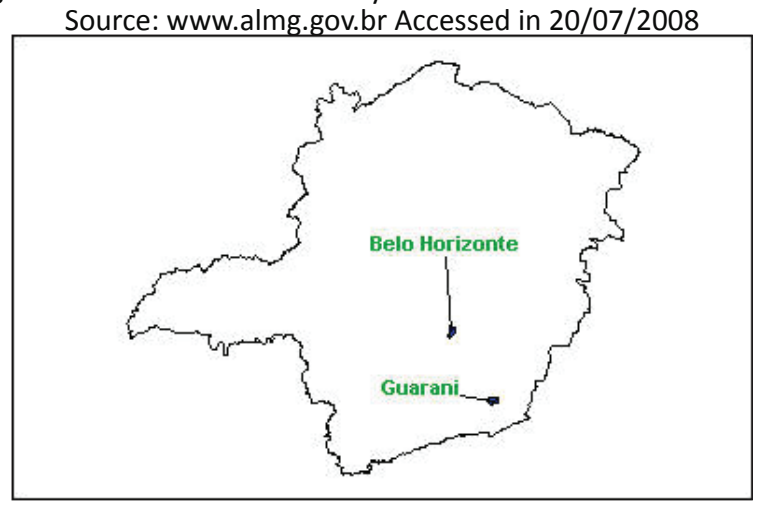

Table 3 presents the Human Development Index (HDI), which has been developed by United Nations Development Program (UNDP) for overseeing how countries are doing for reducing poverty and for improving quality of life. According to UNDP (UNDP, 2008), the human development index is a composite index that measures a country's average achievements in three basic aspects of human development: health, knowledge, and a decent standard of living. The HDI is a figure between zero and one. An index below 0.5 is considered to represent 'low development'. On the other hand, an index of 0.8 or higher is considered to represent 'high development'. Com- 
paring Guarani's figures with the highest in the world (Iceland), with Brazil, with Minas Gerais and with the highest HDI in Minas Gerais - the city of Poços de Caldas, we realize that its situation could be worse and it is below the higher level only in the wealth index and in the general index. Education and health are both regarded as high development situations.

Table 3 - Human Development Index

\begin{tabular}{lcccc}
\hline \multicolumn{1}{c}{ Municipality } & HDI & HDI-GDP & IDHM-Health & IDHM-Education \\
& $\mathbf{2 0 0 0}$ & $\mathbf{2 0 0 0}$ & $\mathbf{2 0 0 0}$ & $\mathbf{2 0 0 0}$ \\
\hline Iceland & 0.968 & 0.985 & 0.941 & 0.978 \\
Brazil (updated figure) & 0.800 & 0.740 & 0.779 & 0.883 \\
Minas Gerais & 0.719 & 0.623 & 0.742 & 0.791 \\
Poços de Caldas (MG) & 0.841 & 0.787 & 0.850 & 0.886 \\
Guarani (MG) & 0.759 & 0.649 & 0.808 & 0.821 \\
\hline
\end{tabular}

Source: UNDP and PNUD

\section{FINDINGS}

The approach to Guarani's Mayor happened following an invitation from him to visit the city in order to help them on management issues. From this meeting, the idea of devising a strategic and performance plan was born. Following indications from literature, the BSC was indicated as a feasible tool through which mission, objectives, targets, actions and performance indicators would be devised. From the Mayors' green light the investigation started and this was carried out according to the framework presented in Figure 2.

In the first meeting, which involved the Mayor, Vice-Mayor, a calendar of interviews with the staff has been agreed and a seminar of integration was set. In this seminar, the main objective was to clarify to the civil servants the aims of the work as well as their contribution. In the seminar, staffs were gathered into affinity groups in order to refine the vision, mission and the main objectives of the administration. The aim was to check out whether people were integrated and specking the same language. At the end of this meeting, a vision, a mission and some key-objectives was set.

At the second stage of the work, another meeting with the mayor and the vice-mayor was set down in order to devise the main directions for the strategic plan of the city. The mayor indicated some guidance's for the performance management framework pointing out where he would like to see the city in terms of revenue per capta, education, health and environment.

At the third stage of the while semi structured interviews were carried out with civil servants and staffs, the research team got involved with analysing documents produced by the administration. The interviews were conducted in order to give as much freedom as possible to respondents to express themselves and to contribute to the definition of objectives, targets, actions and performance indicators for their department. Worthy to mention, that focus group where conducted with some senior officers in order to devise better targets and the appropriate performance indicators for each secretariat. After two months of interviews and analysis, the strategic map was devised. Table 4 presents the results of this stage of the research. 
Table 4 - Guarani's Strategic Map based on BSC

\begin{tabular}{|c|c|c|c|c|c|c|c|}
\hline \multicolumn{8}{|c|}{$\begin{array}{l}\text { Mission: to improve the local community quality of life through compromising with the quality of services, } \\
\text { efficiency and accountability. }\end{array}$} \\
\hline Dimensions & \multicolumn{7}{|c|}{ Objectives } \\
\hline & $\begin{array}{l}\mathrm{X} \text { - To improve } \\
\text { social assis- } \\
\text { tance services }\end{array}$ & \multicolumn{2}{|c|}{\begin{tabular}{|l|} 
XI - To improve \\
the perfor- \\
mance of Educa- \\
tion and Culture
\end{tabular}} & $\begin{array}{l}\text { XII - To im- } \\
\text { prove the qual- } \\
\text { ity of public } \\
\text { premises }\end{array}$ & \multicolumn{2}{|c|}{$\begin{array}{l}\text { XIII - To im- } \\
\text { prove water } \\
\text { supply and } \\
\text { sewer quality }\end{array}$} & $\begin{array}{c}\text { XIV - To improve } \\
\text { environment } \\
\text { care }\end{array}$ \\
\hline Financial & \multicolumn{2}{|c|}{$\begin{array}{c}\text { VII - To pursue better con- } \\
\text { ditions on negotiations } \\
\text { with suppliers }\end{array}$} & \multicolumn{3}{|c|}{$\begin{array}{l}\text { VIII - To seek new alterna- } \\
\text { tives for funding }\end{array}$} & \multicolumn{2}{|c|}{ IX - To reduce costs } \\
\hline $\begin{array}{l}\text { Internal Processes } \\
\text { Business }\end{array}$ & \multicolumn{2}{|c|}{$\begin{array}{l}\text { IV - To preserve the prem- } \\
\text { ises and facilities }\end{array}$} & \multicolumn{3}{|c|}{$\begin{array}{c}\text { V - To improve the efficien- } \\
\text { cy of the processes }\end{array}$} & \multicolumn{2}{|c|}{$\begin{array}{l}\text { VI - To improve the informa- } \\
\text { tion system }\end{array}$} \\
\hline $\begin{array}{l}\text { Learning and } \\
\text { Growth }\end{array}$ & \multicolumn{2}{|c|}{$\begin{array}{l}\text { I - To develop civil serv- } \\
\text { ants skills }\end{array}$} & \multicolumn{3}{|c|}{$\begin{array}{l}\text { II - To improve Human Re- } \\
\text { sources Management }\end{array}$} & \multicolumn{2}{|c|}{$\begin{array}{l}\text { III - To improve staffs and } \\
\text { civil servants' motivation }\end{array}$} \\
\hline
\end{tabular}

Source: Data Findings

The fourth stage was a meeting with the whole set of people involved in order to validate the results. At the beginning of the meeting and as there were some people that didn't attend the other activities, some explanations about performance indicators were provided, such as what is a performance indicator, what is its contribution to management, how to control and to oversee them and what actions can be devised from the process of controlling performance indicators. After this preliminary information, the team was introduced to the Balanced Scorecard, in which Guarani's mission, main objectives, targets, performance indicators, and actions were presented. In order to facilitate their job, they were presented with a manual in which the main information was provided.

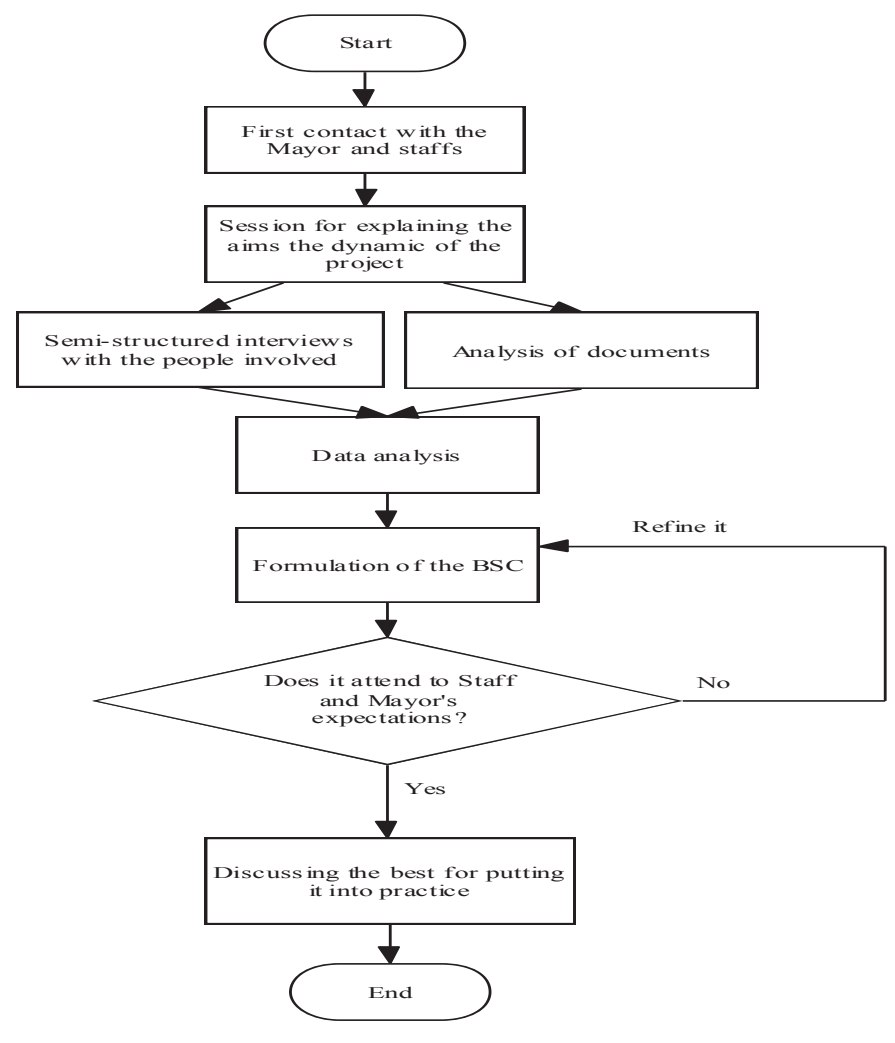

Figure 2: Action Research Framework Source: Research Framework 


\section{DISCUSSION}

Performance management has been in the public sector agenda since New Public Management came into action in the 1980'. Since then, public sector organizations have been involved on developing and implementing schemes for improving performance and offering better quality services to the local community. Most of the initiatives were based on adapting business-based tools for improving performance. One of the most famous tools is inarguably the Balanced Scorecard, which has been implemented in public sector organizations all around the world. Despite this, the literature does not provide empirical evidence about the implementation of the BSC in Brazilian local government.

In this paper, we present an attempt of implementing the BSC in a small-scale municipal district located at the southeast region of the State of Minas Gerais - Brazil. The endeavour presented here, followed the action research investigation carried out in order to gather staff and civil servants compromise to the success of the implementation. For so doing, we followed the eight determinant factors success for implementing the BSC in a municipal setting as suggested by Chan (Chan, 2004) after surveying municipal government from USA and Canada. Below we present each of the suggestion confronting with evidence gathered at the field. In this paper, we report the results of the development of the BSC in Guarani. The contribution provided by the follows is of twofold: it is a theoretical contribution in the extent that it provides empirical evidences that the BSC is a feasible tool for local governments, and it is also a practical contribution as we suggest a set of performance indicators that could be put to practice in any small-scale municipalities.

\section{1) Top management commitment and leadership buy-in}

This was a determinant factor for implementing BSC in the Municipal District of Guarani. We only started the process after being assured that the Mayor and Vice-Mayor was both at the helm of the ship and they really desired that things got changed in the municipal district. This was particularly true to the extent that the Mayor participated in all activities and meetings throughout the process. Staffs delivered strong evidence that this was the real situation and not something that was done for impressing the research team.

\section{2) Departmental, middle-manager and civil servant participation and buy-in}

Action research facilitated staffs and civil servants participation in the extent that they were responsible for defining objectives, targets, performance indicators, and actions. Without their support things would be very difficult to the research team who was neither not familiar with several aspects of Guarani day-to-day activities, nor with some specificities of the work at hand. The issue related to this aspect is that as participating in the process, the co-ownership of management team and civil servants increase in a great deal.

\section{3) Culture of performance excellence}

This was a difficult moment for the research team. Guarani's management team was not accustomed with performance management and performance indicators. At the very first moment, they regarded the endeavour as a waste of time and resources and that the initiative would not bring any improvement to the city and to the city hall. The Mayor's leadership was therefore imperative to the fulfilment of the project.

\section{4) Training and education}

Guarani's staffs and civil servants have not participated in any training whatsoever up to the moment of the implementation of the BSC. The fact that HR was dealt with as so is clear evidence that this department was solely occupied with recording new contracts and producing the payment sheet. With the implementation of the BSC, people started to take HR more seriously 
in order to pave the innovations required by the new strategic and performance management.

\section{5) Keeping it relatively simple, easy to use and understand}

The research team tried to keep the BSC implementation as easy as possible in order to gather cooperation from staffs and civil servants. As one of the section participant said, "no one compromise himself with something that he does not understand" (Accounting Controller). At the end of the final section, the word BSC was integrated in their vocabulary. Some of them were not able to speak 'Balanced Scorecard' due to language issues, but they had worked out a way for telling to the research team that they had assimilated the message.

\section{6) Clarity of vision, strategy and outcome}

The clarity of the vision and of the mission was achieved at the first section when the Mayor asked the audience to speak in their own words what they expect to be a mission of the administration. In his own words: "Please, tell me what moves you out of bed every morning to come to the city hall and to give your best for Guarani's citizens?"

\section{7) Link of balanced scorecard to incentive}

This was not over the table the moment we started the BSC implementation in Guarani. The Mayor refused to link the implementation to incentives because he was not sure whether the initiative would be the successful the research team was expecting. Despite, his primary position against the incentive, he promised to review it as soon as the BSC started make strategy and performance management easy, useful and promissory.

\section{8) Resources to implement system}

The research project was implemented with resources from the State Government of Minas Gerais through grants provided by FAPEMIG (Support to the Research in the State of Minas Gerais Foundation). The city hall was responsible for some expenses, such as refreshment for the meetings, transportation for some staffs and civil servants and other small expenses. At the beginning the Mayor was a little sceptical about why Guarani had been chosen among hundreds of other municipal districts in the region. But, the research team leader explained to him that the decision was made due to his engagement to the success of the project.

\section{FINAL REMARKS}

Public sector managers have been struggling to find out the means to devise useful strategies and performance measures for keeping society confident and satisfied. This was the main motive behind the New Public Management and this has been the road public managers have been walking for keeping their place within public administration. The Balanced Scorecard is another attempt for doing so. It has been transported from private sector implemented as it was devised in some cases, adapted to fit public organization aims and needs in other cases.

The literature provides empirical evidence that the BSC can be successfully implemented in public sector organizations. Indeed, Kaplan and Norton (2001) suggested that the order of importance of some dimensions should be changed in order to fit better to this different sort of organization (prioritizing constituents rather than finance). Guarani's experience has proved that the literature is right and the BSC could be a feasible tool to public sector organizations put strategic management to practice. By using the BSC, we managed to devise objectives, targets, performance indicators and actions that would help to improve the human development of the city if it is followed as such. The literature to date didn't have any evidence of the feasibility of doing so in in-developing settings.

The difference we realized across the process is related to the leadership of the Mayor. 
Some staffs and civil servants were very sceptical about the BSC future in Guarani if other different ideology came into power. As stated by one civil servant: "the first moment another mayor assumes the city hall, the BSC will be part of the past and everything will be forgotten. This is the way things go on in politically managed organizations". There is nothing the research team could do about the discontinuity of the electoral process, because this is part of the democratic rules of the game. Changes are inevitable due to the lasting of political mandates. Nevertheless, the seed has been planted. This administration is just about to come to an end and the Mayor leave is supposed to leave the city hall, but the civil servants will stay and, if they are keen on the importance of the tool, they will managed to keep it alive for the next administration.

In this paper, we present an investigation carried out with one Brazilian small-scale municipal district trying to prove that BSC fits to this particular kind of organization. The all thing needed is to gain compromise from leaders and from staffs. The moment they assume it will help them on making strategic and performance management easier and more effective, they will buy-in the idea and put it into practice. The Guarani's case study has proved this issue by the evidence gathered throughout the data collection process. In focus groups sections as well as in interviews, staffs and civil servants admitted that after the BSC they started focusing on results rather than on processes and strategy is now part of their daily activities.

In terms of the research question devised, the analysis proved staffs and civil servants do react well to the implementation of the BSC as a strategic management tool depending upon Mayor's leadership. They also see the BSC as a useful tool to help them to manage performance to the extent that feasible performance indicators are devised. The evidence also corroborated Chan's suggestions of determinant factors to success in the implementation of the BSC in public organizations.

Our conclusion is that the BSC is a feasible strategy and performance management tool to be implemented in small-scale municipal districts. It seems to be heavily dependent upon Mayor's leadership and upon staffs and civil servants' engagement. Another issue that is very likely to facilitate the process is related to the way it is conducted. The most involved with the aims and with the operation of the process people get the more success it is likely to achieve. In this investigation, the research team gave to civil servants and to the staff the opportunity of influencing objectives, targets, actions and the performance indicators were devised. This modus operandi made the whole people involved in the process and more responsible to the success of the BSC implementation.

As every investigation, this research has its limitations related to time and to the methods employed. As an action research, the findings are based on the perceptions and ideas presented by the people who worked for the municipality the time the investigation was carried out. This could be different now and the investigation needs to be replicated once again in the same municipality in order to corroborate and to date the findings and conclusions presented in this article. Another limitation lies on the length of time between the data collection and the writing of this paper. It has taken some time to make sense about some issues indicated in the action research sessions due to the complexity of analyzing videotape data. Though not invalidating the results presented here, it is another indication that the research needs to be replicated. 


\section{REFERENCES:}

ASKIM, J. 2004. Performance Management and Organizational Intelligence: adapting the Balanced Scorecard in Larvik Municipality. International Public Management Journal, 7, 415-438.

BALL, R. 1998. Performance Review in Local Government, Asfgate Publishing Company.

BERMAN, E. M. 2006. Performance and Productivity in Public and Nonprofit Organizations, New York, M.E. Sharpe.

BRASIL 2007. Contagem Populacional - 2007. In: ESTATísTICA, I.-I. B. D. G. E. (ed.). Brasília: IBGE.

BRASIL 2011. Sinopse do Censo Demográfico de 2010. In: ESTATÍSTICA, I. B. D. G. E. (ed.). Brasília: IBGE.

BRYMAN, A. 2008. Social research methods, Oxford, Oxford University Press.

CARMONA, S. \& GRÖNLUND, A. 2003. Measures vs actions: the balanced scorecard in Swedish Law Enforcement. International Journal of Operations \& Production Management, 23, 1475-1496.

CHAN, Y.-C. L. 2004. Performance measurement and adoption of balanced scorecards: A survey of municipal governments in the USA and Canada. International Journal of Public Sector Management, 17, 204-221.

CRUZ, J. A., QUANDT, C. O., MARTINS, T. S. \& SILVA, W. V. D. 2010. Performance Analysis of the Third Sector - Approach to Accountability: A case study in Brazilian NGO. Rev. Adm. UFSM, 3, 58-75.

FARNETI, F. \& GUTHRIE, J. 2008. Italian and Australian local governments: balanced scorecard practices. A research note. Journal of Human Resource Costing \& Accounting, 12, 4-13.
GOMES, R. C. \& LIDDLE, J. 2009. The balanced scorecard as a performance management tool for third sector organizations: the case of the Arthur Bernardes foundation, Brazil. BAR. Brazilian Administration Review, 6, 354-366.

GREATBANKS, R. \& TAPP, D. 2007. The impact of balanced scorecards in a public sector environment Empirical evidence from Dunedin City Council, New Zealand. International Journal of Operations \& Production Management, 27, 846-873.

HOOD, C. 1995a. Contemporary Public Management: a new global paradigm? Public Policy and Administration, 10, 104-117.

HOOD, C. 1995b. The "New Public Management" in the 1980s: variations on a theme. Accounting, Organizations and Society, 20, 93-109.

HOQUE, Z. 2008. Measuring and reporting public sector outputs/outcomes: exploratory evidence from Australia. International Journal of Public Sector Management, 21, 468-493.

KAPLAN, R. S. \& NORTON, D. P. 1992. The Balanced Scorecard - Measures That Drive Performance. Harvard Business Review, 70, 71-79.

KAPLAN, R. S. \& NORTON, D. P. 1996. The Balanced Scorecard: translating strategy into action, Boston, Harvard Business School Press.

KAPLAN, R. S. \& NORTON, D. P. 2001. Transforming the Balanced Scorecard from Performance Measurement to Strategic Management: Part I. Accounting Horizons, 15, 87-104.

KLOOT, L. 1999. Performance measurement and accountability in Victorian local government. International Journal of Public Sector Management, 12, 565-583.

LEE, N. 2006. Measuring the performance of public sector organisations: a case study on public schools in Malaysia. Measuring Business 
Excellence, 10, 50-64.

MCADAM, R., HAZLETT, S.-A. \& CASEY, C. 2005. Performance management in the UK public sector: addressing multiple stakeholder complexity. International Journal of Public Sector Management, 18, 256-273.

MOSS, Q. Z., ALHO, J. \& ALEXANDER, K. 2007. Performance measurement action research. Journal of Facilities Management, 5, 290-300.

MOYNIHAN, D. P., FERNANDEZ, S., KIM, S., LEROUX, K. M., PIOTROWSKI, S. J., WRIGHT, B. E. \& YANG, K. 2011. Performance Regimes Amidst Governance Complexity. Journal of Public Administration Research and Theory, 21, i141-i155.

MOYNIHAN, D. P. \& PANDEY, S. K. 2010. The Big Question for Performance Management: Why Do Managers Use Performance Information? Journal of Public Administration Research and Theory, 20, 849-866.

PETERS, T. J. \& WATERMAN, R. H. 1982. In search of excellence, lessons from America's best-run companies, New York, Harper and Row.

PORTER, M. E. 1985. Competitive Advantage: Creating and Sustaining Superior Performance, New York, Free Press.

PORTER, M. E. 1991. Towards a Dynamic Theory of Strategy. Strategic Management Journal, 12, 95-117.

PORTER, M. E. 1998. The Competitive Advantage of Nations, London, MACMILLAN PRESS LTD.

RICCUCCI, N. M. 2001. The "Old" Public Management versus the "New" Public Management: Where Does Public Administration Fit in? Public Administration Review, 61, 172-175.

RUAS, E. B. 2003. Criação de Indicadores Estratégicos para o Instituto de Pesquisas
Tecnológicas do Estado de São Paulo S.A. - IPT. RAE-eletrônica, 2, 1-18.

SILVA, F. D. A. E. \& GONÇALVES, C. A. 2011. The process of formulating and implementing strategic planning in public sector institutions. Rev. Adm. UFSM, 4, 458-476.

SINCLAIR, D. \& ZAIRI, M. 1995. Effective Process Management through Performance Measurement. Part II - Benchmarking total quality based performance measurement for best practice. Business Process Re-engineering \& Management Journal, 1, 58-72.

UNDP. 2008. The Human Development Index (HDI) [Online]. New York: UNDP. [Accessed June, 15th 2008].

WISNIEWSKI, M. \& OLAFSSON, S. 2004. Developing balanced scorecards in local authorities: a comparison of experience. International Journal of Productivity and Performance Management, 53.

WOODS, M. \& GRUBNIC, S. 2008. Linking comprehensive performance assessment to the balanced scorecard: evidence from Hertfordshire County Council. Financial Accountability \& Management, 24, 343-361.

YeTANO, A. 2009. Managing Performance at Local Government Level: The Cases of the City of Brisbane and the City of Melbourne. Australian Journal of Public Administration, 68, 167-181.

YIN, R. K. 2003. Case Study Research: design and methods, Thousand Oaks, Sage Publications. 